\title{
Cercaria corbiculae sp. nov. in a Brackish Water Clam Corbicula japonica PRIME from Lake Shinji, Shimane Prefecture, Japan
}

\author{
Shigeru SHImura \\ Department of Fisheries, Faculty of Agriculture, University \\ of Tokyo, Yayoi, Bunkyo-ku, Tokyo 113, Japan
}

(Received July 4, 1983)

\begin{abstract}
A monorchiid cercaria was found in a brackish water clam Corbicula japonica collected from Lake Shinji, Shimane Prefecture, Japan, and a new name Cercaria corbiculae sp. nov. is proposed. The present species is a distome, pharyngeate cercaria with a slender long tail, no stylet, no eyespots, long ceca, three pairs of penetration gland cells, 16 flame cells, a saccate excretory vesicle deflected to left.
\end{abstract}

\section{Introduction}

In the course of a series of parasitological investigation on marine and brackish water cercariae, a new cercaria was discovered in Corbicula japonica collected from Lake Shinji, Shimane Prefecture. C. japonica is a brackish water clam living in estuaries and lagoons on bottom of silty sand, and one of important commercial shellfishes in Japan. The present paper describes the cercaria under the name Cercaria corbiculae sp. nov.

\section{Materials and Methods}

Samples for the present study were collected from Lake Shinji, Shimane Prefecture (map reference, $35^{\circ} 27^{\prime} \mathrm{N}, 132^{\circ} 58^{\prime} \mathrm{E}$ ). A total of 419 Corbicula japonica were taken in March and November 1982. They were examined for cercariae by dissecting their soft body under a binocular dissecting microscope. A squash preparation of the soft body was also examined for encysted trematodes. For morphological observations of the cercaria, especially of the excretory system, living specimens were gently flattened under coverslip pressure and sealed with clear finger-nail polish. The description was based on mature cercariae, both living and preserved in formalin. Neutral red was used as intravital stain. Measurements were made on twenty mature specimens fixed in hot formalin without excessive coverslip pressure. Semidiagrammatic drawings were made to scale from such measurements. For histological examination, the gonad and digestive gland of infected clams were fixed in formalin, embedded in paraffin, and sectioned at 4-6 $\mu \mathrm{m}$. Sections were stained with Ehrlich's hematoxylin and eosin:

\section{Description of the Species}

Presumptive adult form: Monorchiidae

Host: Corbicula japonica PRIME (Corbiculidae)

Locality: Lake Shinji, Shimane Prefecture

Date and infection rate:

$$
\text { March 7, 1982: } \quad 1 / 184(0.5 \%)
$$

November 12, 1982: 6/510 (1.2\%)

Measurements: mean (range in parentheses) in microns

Cercaria body..$\ldots \ldots \ldots \ldots \ldots \ldots \ldots \ldots \ldots$ ..281 (266-295) long by 100 (90-109) wide; oral sucker ................... .....49 (46-51) long by 47 (44-51) wide; prepharynx............ $8(0-12)$ long; pharynx $\ldots \ldots \ldots \ldots \ldots \ldots \ldots \ldots \ldots$ ......19 (17-22) long by 19 (17-22) wide; acetabulum .................... $\ldots \ldots .46$ (41-51) long by $46(44-51)$ wide;

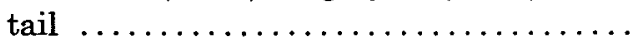
...203 (179-223) long by 20 (29-31) wide; 
Sporocyst

body $\ldots \ldots \ldots \ldots \ldots \ldots \ldots \ldots \ldots \ldots$

861 (637-1,009) long by 264 (216-314) wide.

Specimen: Meguro Parasitological Museum, Tokyo:

MPM Coll. No. 19370

\section{Specific Description (Figs. 1, 2)}

Distome, pharyngeate cercaria with a slender long tail (Fig. 1a). The body surface is covered with minute, backward directed spines being more sparse posteriorly than anteriorly. No sensory hairs are recognized. The oral sucker is well developed, globular, and located at the anterior end of the body. The stylet is absent. The mouth opening is followed by a short prepharynx. The pharynx is globular. The digestive tract bifurcates a short distance anterior to the acetabulum into two long and slender ceca running through the lateral field near to the posterior end. The tract is deeply stainable with neutral red. Eye-spots are lacking. Three pairs of penetration gland cells are situated in the middle part of the body, immeadiately anterior to the acetabulum. Their ducts on each side of the body twist into one bundle, run anteriorly and separate individually to open near the apical end of the oral sucker. The penetration gland cells are faintly stained with neutral red, but their ducts are deeply stained. The acetabulum is also well developed, almost equal in size to the oral sucker, and situated in the posterior part of the middle third of the body. The genital anlage is slightly discernible in the posterodextral part of the acetabulum. The excretory vesicle is large and long, lined with a layer of epithelial cells, extending to the anterior end of the acetabulum, displacing sinistrally in the middle part by the genital anlage and then curved inward at its anterior end. Main collecting ducts are ciliated, arise on each lateral side in the middle part of the vesicle, run forward, and divide into an anterior and a posterior branch on the middle level of the acetabulum. Each of these branches drains two sets of two flame cells; thus the flame cell formula is $2[(2+2)+(2+2)]$ $=16$. The slender and aspinose tail is about two thirds of body length. No caudal excretory tube is observed.

The sporocyst is oval, thick-walled with a birth pore at one end, contains 3-7 cercariae and some germ balls (Fig. 1b). Sporocysts are only found in the gonad by histological observations. Reproductive cells of the host

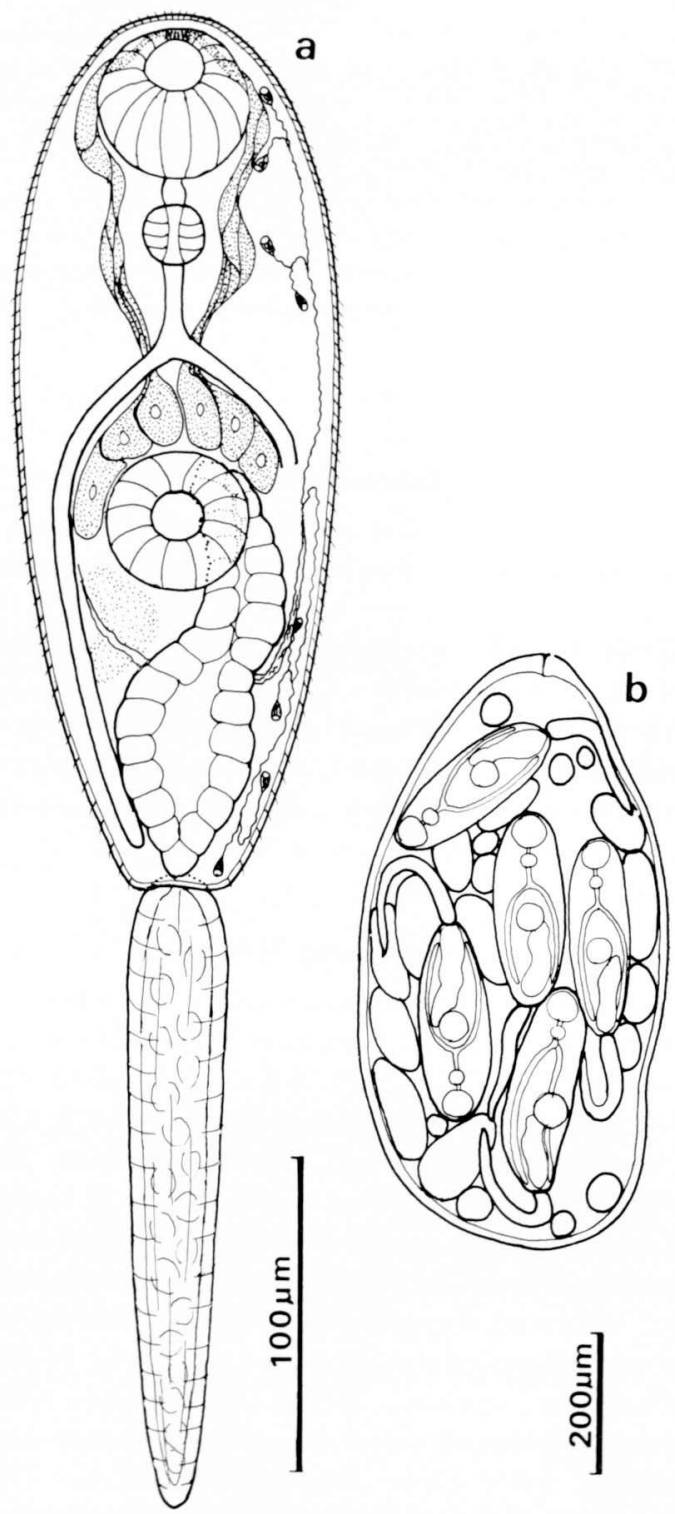

Fig. 1. Cercaria corbiculae sp. nov. a: cercaria, general feature, ventral view, b: ripe sporocyst with mature cercariae and germ balls. 


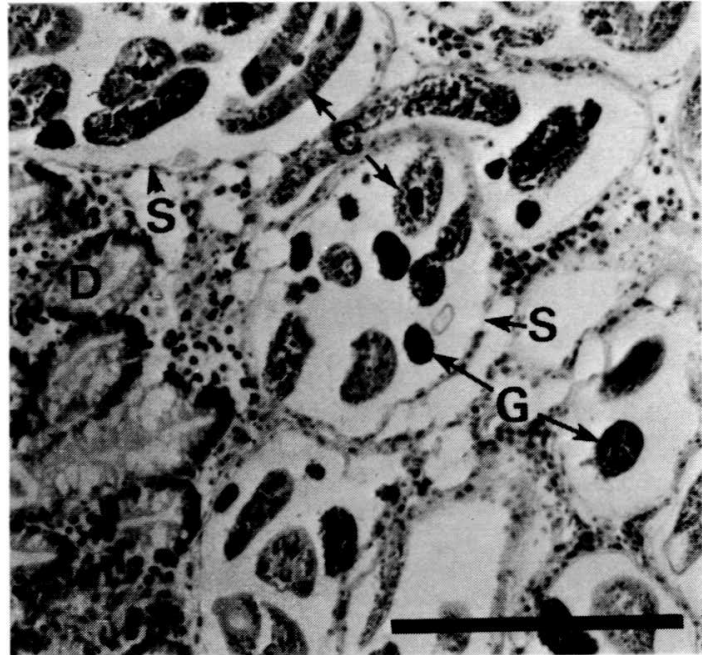

Fig. 2. Cross section of gonad and digestive gland of Corbicula japonica infected by sporocysts of Cercaria corbiculae, sp. nov. C: cercaria, D: digestive gland, $\mathrm{G}$ : germ ball, $\mathrm{S}$ : sporocyst wall. Scale bar, $200 \mu \mathrm{m}$.

are almost completely lacking. The digestive gland is not infected (Fig. 2).

The specific name, corbiculae, refers to the generic name of the first intermediate host.

\section{Discussion}

Following characteristics of the present cercaria probably demonstrate inclusion in the family Monorchiidae (CABLE, 1956; Holliman, 1961); distome, pharyngeate, no stylet, thick-walled saccate excretory vesicle, 16 flame cells, and development in sporocyst. Monorchiid cercariae with a long tail have been reported only a few; cercaria of Monorcheides cumingiae (=Cercaria cumingiae) (Martin, 1938, 1940), cercaria of Postmonorchis donacis (Young, 1953), Cercaria caribbea LXIII, C. caribbea LXIV (CABLE, 1963), C. ophicerca (PALOMBI, 1934), C. longicaudata (BARTOLI, 1966), C. cerastodermae I (SANNIA and JAMES, 1978). The first three species have eyespots, two pairs of penetration gland cells, short ceca and a long tail bearing peculiar lateral lappets on each side. C. ophicerca and $C$. longicaudata have eye-spots and a very long tail. C. cerastodermae $I$ has four pairs of penetration glands and a $\mathrm{V}$-shaped excretory vesicle and develops in a unique sporocyst. C. caribbea $L X I V$ has a saccate excretory vesicle deflected to left and no eyespots. C. caribbea LXIV seems to be closely related to the present cercaria. But the former is much smaller than the latter, and has two pairs of penetration gland cells and indistinct ceca. Therefore, the present cercaria clearly differs from all described species and is regarded as a new species.

Cercariae of some monorchiid trematodes were reported to leave the host and to encyst in the same host or in another pelecypod (Martin, 1940; Young, 1953; DeMartini and Pratt, 1964). A squash preparation of the soft body of Corbicula japonica was examined for trematodes, but no encysted metacercariae were observed.

\section{Acknowledgements}

I would like to thank Professor J. Iто, Faculty of Education, Shizuoka University, for his criticism of the manuscript, and Dr. Marianne KøIE, Marine Biological Laboratory, Denmark, for her valuable comments on the systematic position of the cercaria. Thanks are also due to Mr. M. Nakamura, Mitoya Branch of Shimane Prefectural Fisheries Experimental Station, for providing samples of clams, and to Mr. T. YoshinaGa, for his technical assistance.

\section{References}

BArtoli, P. (1966): Contribution à l'étude des stades larvaires des Trématodes marins du littoral des Bouches-du-Rhône (France): Cercaria longicaudata n. sp. (Monorchiidae). Annls. Parasit., 41, 301-306.

Cable, R. M. (1956): Scientific survey of Porto Rico and the Virgin Islands. Marine cercariae of Puerto Rico. N.Y. Acad. Sci., 16, Part 4, 491-577.

CABle, R. M. (1963): Marine cercariae from Curaçao and Jamaica. Z. Parasitenk., 23, 429-469.

DeMartini, J. D. and Pratt, I. (1944): The life cycle of Telolecithus pugetensis LLOYD and Guberlet, 1932 (Trematoda: Monorchidae). J. Parasit., 50, 101-105.

Holliman, R. B. (1961): Larval trematodes from the Apalachee Bay area, Florida, with a check- 
list of known marine cercariae arranged in a key to their superfamilies. Tulane Stud. Zool., 9, 1-74.

MarTIN, W. E. (1938): Studies on trematodes of Woods Hole; The life cycle of Lepocreadium setiferoides (MILLER and NoRTHUP), Allocreadiidae, and the description of Cercaria cumingiae n. sp. Biol. Bull., 75, 463-474.

MarTin, W. E. (1940): Studies on the trematodes of Woods Hole. III. The life cycle of Monorcheides cumingiae (MARTIN) with special reference to its effect on the invertebrate host. Biol. Bull., 79, 131-144.

Palombi, A. (1934): Gli stadi larvali dei Tre- matodi del Golfo di Napoli. $1^{\circ}$. Contributo allo studio della morfologia, biologia e sistematica delle cercarie marine. Pubbl. Staz. Zool. Napoli, 14, 51-94.

SANNIA, A. and JAMES, B.L. (1978): The morphology of Cercaria cerastodermae I nom. nov. (Monorchiidae) (=Cercaria lepidapedon rachion (CoBbold, 1858) sensu LEBour, 1908) a rare digenean parasite of the cockle in Britain. J. Nat. Hist., 12, 487-500.

Young, R. T. (1953): Postmonorchis donacis, a new species of monorchid trematode from the Pacific coast, and its life history. J. Wash. Acad. Sci., 43, 88-93.

\section{島根県穴道湖産のヤマトシシミに笴生するセルカリアの 1 新種 \\ 志村, 茂* \\ (昭和 58 年 7 月 4 日受理)}

島根県穴道湖産のヤマトシジミから Monorchiidae に属するセルカリアを検出し, 新種と認めて Cercaria corbiculae sp. nov. と命名記載した。本種は細長い尾を備えたセルカリアで, 口吸盤, 咽頭, 腹吸盤 がよく発達しており, 眼点と穿刺棘を持たない。侵入腺細胞は 3 対ある。排泄裴は長い雊状で, 前半部が左 㫬炕偏向する。炎細胞式は $2[(2+2)+(2+2)]=16$ である。セルカリフはスポロシスト内で発育する。 